\title{
GAMBARAN SISA MAKANAN PASIEN DI RSUD PETALA BUMI PROVINSI RIAU
}

\author{
Putri Lestari*, Yessi Marlina \\ Jurusan Gizi, Poltekkes Kemenkes Riau, Indonesia \\ Jl. Melur No 103 Kel. Harjosari, Kec. Sukajadi, Pekanbaru, Riau \\ Telp./Fax 082170315893 \\ Email: putrilestari26.gz@gmail.com
}

Article Info
Article history:
Received January $14^{\text {th }}, 2021$
Revised February $21^{\text {th }}, 2021$
Accepte March $25^{\text {th }}, 2021$

Keyword:

Comstock; Food Waste

\begin{abstract}
Background : The high amount of leftover food is a serious problem that must be addressed immediately because the food served in the hospital has taken into account the quantity and quality according to the patient's needs. This also indicates that nutrition services are not achieved. The purpose of this study was to describe the leftover in Petala Bumi Hospital, Riau Province by classifying based on meal time, treatment class, food texture and type of diet.

Research Methods : The study used cross sectional design. The population of this study were all patients in room 1 stclass, 2 nd class and 3rd class with a total sample of 8 people using purposive sampling method. The leftover was measured using a 6-point Comstock scale for 3 days including breakfast, lunch, dinner, morning and evening snacks.
\end{abstract}

Research Result : The results showed that leftover was mostly found in animal side dishes of the lunch menu $(87,5 \%)$, blenderized food in first class (100\%0, and low-salt and high-fiber diets (100\%).

Conclusion : The most leftovers are in blenderized foods and lowsalt and high-fiber diets.

\begin{abstract}
ABSTRAK
Latar Belakang : Tingginya sisa makanan merupakan masalah serius yang harus segera ditangani karena makanan yang disajikan di rumah sakit telah memperhitungkan jumlah dan mutu menurut kebutuhan pasien. Hal ini juga mengindikasikan tidak tercapainya pelayanan gizi. Tujuan penelitian ini untuk mengetahui gambaran sisa makanan di RSUD Petala Bumi Provinsi Riau dengan menggolongkan sisa makanan berdasarkan waktu makan, kelas perawatan, bentuk makanan dan jenis diet.
\end{abstract}

Metode Penelitian : Jenis penelitian ini bersifat deskriptif dengan desain cross sectional. Populasi penelitian ini adalah seluruh pasien di ruang rawat inap kelas I, II dan III RSUD Petala Bumi dengan jumlah sampel sebanyak 8 orang menggunakan metode purposive sampling. Sisa makanan diukur menggunakan skala Comstock 6 point selama 3 hari meliputi makan pagi, makan siang, makan malam serta selingan pagi dan sore.

Hasil Penelitian : Sisa makanan terbanyak berasal dari lauk hewani pada waktu makan siang (87,5\%). Kelas perawatan yang makanannya bersisa yaitu kelas I yang mendapatkan bentuk makanan saring (100\%). Berdasarkan jenis diet, sisa makanan diet tinggi serat dan rendah garam bersisa (100\%).

Kesimpulan : Sisa makanan terbanyak yaitu pada makanan saring 


\section{PENDAHULUAN}

Penyelenggaraan makanan sebagai salah satu sarana penunjang dalam pelayanan kesehatan bertujuan untuk mencukupi kebutuhan pasien terhadap gizi seimbang. Komponen penting dalam kesuksesan penyelenggaraan makanan rumah sakit berorientasi pada kepuasan pasien. Kepuasan pasien terhadap penyelenggaraan makanan dapat diidentifikasi dari ekspektasi produk dan persepsi pasien terhadap kualitas pelayanan. Salah satu indikator Standar Pelayanan Minimun (SPM) adalah melihat sisa makanan pasien. Sisa makanan pasien ini akan mempengaruhi tingkat kepuasan dari pasien (Depkes 2013a).

Menurut Asosiasi Dietisien Indonesia (2005) sisa makanan adalah jumlah makanan yang tidak dimakan oleh pasien dari yang disajikan rumah sakit menurut jenis makanannya. Di Indonesia, sisa makanan di berbagai rumah sakit cukup tinggi dengan melihat banyaknya pasien yang meninggalkan sisa makanan 17,67\% (Aula 2011). Data ini jauh di atas 20\% persentase minimal sisa makanan (Depkes 2013b).

Tingginya sisa makanan merupakan masalah serius yang harus segera ditangani karena makanan yang disajikan di rumah sakit telah memperhitungkan jumlah dan mutu menurut kebutuhan pasien (Lumbantoruan 2012). Pasien yang tidak menghabiskan makanan dalam waktu lama akan menyebabkan pasien mengalami defisiensi zat gizi. Ini berarti pelayanan gizi tidak tercapai (Kapantow and Kandou 2016). Secara ekonomis menunjukkan banyaknya biaya yang terbuang, yang menyebabkan anggaran makanan kurang efisien dan efektif, sehingga pengelolaan biaya makan tidak mencapai tujuan yang optimal (Wahyunani 2017).

Sisa makanan diukur dengan menimbang sisa makanan untuk setiap jenis hidangan yang ada di alat makan atau dengan cara taksiran visual menggunakan skala Comstock 6 point. Sisa makanan dapat memberikan informasi yang tepat dan terperinci mengenai banyaknya sisa atau banyaknya makanan yang dikonsumsi oleh perorangan atau kelompok (Puruhita et al. 2014). Kemungkinan didapatkan perbedaan sisa makanan pasien pada waktu makan, kelas perawatan, bentuk makanan dan jenis diet.

RSUD Petala Bumi merupakan Rumah Sakit milik Pemerintah Provinsi Riau selain RSUD Arifin Ahmad dan RSJ Tampan. RSUD Petala Bumi kini telah berkembang pesat yang dapat dilihat dari tingkat Based Ocupation Ratio (BOR) pada tahun 2016 31,5\% kini mencapai $72 \%$ dengan 63 kapasitas tempat tidur (RSUD Petala Bumi 2016). Semakin banyaknya pasien yang dilayani, rumah sakit akan meningkatkan kinerja pelayanannya, salah satunya dalam penyelenggaraan makannya. Bentuk penyelenggaraan makanan yang digunakan di RSUD Petala Bumi adalah semi out-sourcing yang pelaksanaannya diawasi penuh oleh ahli gizi rumah sakit.

Tolak ukur keberhasilan penyelenggaraan makanan adalah makanan yang disajikan dapat diterima dan makanan tersebut habis termakan tanpa meninggalkan sisa makanan (Julia et al. 2018). Standar minimal sisa makanan di RSUD Petala Bumi adalah 20\%. Berdasarkan data sisa makanan yang dibedakan menurut kelas perawatan diketahui bahwa masih ditemukan sisa makanan di RSUD Petala Bumi.

Dari uraian di atas peneliti tertarik untuk mengetahui gambaran sisa makanan di RSUD Petala Bumi Provinsi Riau dengan menggolongkan sisa makanan berdasarkan waktu makan, kelas perawatan, bentuk makanan dan jenis diet.

\section{METODE PENELITIAN}

Jenis penelitian ini bersifat deskriptif dengan desain cross sectional. Penelitian ini dilaksanakan di RSUD Petala Bumi pada bulan November 2018 sampai Mei 2019. Cara pengukuran sisa makanan menggunakan metode visual comstok. Populasi penelitian ini adalah seluruh pasien yang berada di ruang rawat inap kelas I, II dan III RSUD Petala Bumi. Teknik pengambilan sampel menggunakan purposive sampling yaitu suatu teknik mengambilan sampel dengan cara menetapkan kriteria inklusi dan ekslusi. Adapun kriteria inklusi dalam penelitian ini adalah: pasien dewasa berumur 18-60 tahun dengan harapan pasien dewasa dapat memberikan pendapatnya secara langsung, pasien dalam kesadaran baik, pasien dirawat minimal 1 hari perawatan, pasien mendapatkan makanan biasa, lunak dan saring. Dan kriteria ekslusi dalam penelitian ini adalah: makanan dihabiskan oleh keluarga, terjadi perubahan bentuk makanan dalam diit, pasien pulang 
sebelum 3 hari pengambilan data. jadi jumlah pasien yang memenuhi kriteri inklusi penelitian adalah 8 orang..

\section{HASIL PENELITIAN}

Responden dalam penelitian ini adalah pasien rawat inap di RSUD Petala Bumi Provinsi Riau yang berjumlah 8 orang yang memenuhi kriteria inklusi penelitian. Responden dalam penelitian ini berusia antara 18-60 tahun dengan umur termuda 18 tahun sedangkan umur reponden tertua adalah 59 tahun. Adapun karakteristik responden lainnya dapat dilihat pada Tabel 1.

Tabel 1. Distribusi Frekuensi Karakteristik Responden

\begin{tabular}{|c|c|c|}
\hline Karakteristik & $\mathbf{n}$ & $\%$ \\
\hline \multicolumn{3}{|l|}{ Jenis Kelamin } \\
\hline Perempuan & 3 & 37,5 \\
\hline Laki-Laki & 5 & 62,5 \\
\hline \multicolumn{3}{|l|}{ Bentuk Makanan } \\
\hline Makanan Biasa & 1 & 12,5 \\
\hline Makanan Lunak & 6 & 75 \\
\hline Makanan Saring & 1 & 12,5 \\
\hline \multicolumn{3}{|l|}{ Jenis Diet } \\
\hline Tinggi Serat & 1 & 33,3 \\
\hline Diabetes Mellitus & 1 & 33,3 \\
\hline Rendah Garam & 1 & 33,3 \\
\hline \multicolumn{3}{|l|}{ Kelas Perawatan } \\
\hline Kelas I & 1 & 12,5 \\
\hline Kelas II & 2 & 25 \\
\hline Kelas III & 5 & 62,5 \\
\hline \multicolumn{3}{|l|}{ Ruang Perawatan } \\
\hline Lantai 3 & 3 & 37,5 \\
\hline Bedah & 2 & 25 \\
\hline Penyakit Dalam & 3 & 37,5 \\
\hline
\end{tabular}

Berdasarkan hasil distribusi frekuensi pada Tabel 1. dapat dilihat bahwa responden dengan jenis kelamin laki-laki lebih banyak dibandingkan responden perempuan yaitu 62,5\% (5 orang). Berdasarkan bentuk makanan, pasien paling banyak mendapatkan makanan lunak sebanyak $75 \%$ (6 orang) sedangkan berdasarkan kelas perawatan, responden paling banyak dirawat di kelas III sebanyak 62,5\% (5 orang), pasien terbanyak di ruang perawatan penyakit dalam dan di lantai 3 sebanyak 37,5\% (3 orang).

Gambaran Sisa Makanan Pasien di RSUD Petala Bumi Berdasarkan Waktu Makan Tabel 2. Distribusi Frekuensi Sisa Makan Pasien di RSUD Petala Bumi Berdasarkan Waktu Makan

\begin{tabular}{|c|c|c|c|c|c|c|}
\hline \multirow{3}{*}{$\begin{array}{l}\text { Waktu } \\
\text { Makan }\end{array}$} & \multirow{3}{*}{$\begin{array}{c}\text { Rata-rata } \\
(\%)\end{array}$} & \multirow{3}{*}{ Jenis Makanan } & \multicolumn{4}{|c|}{ Sisa Makanan } \\
\hline & & & \multicolumn{2}{|c|}{ Bersisa } & \multicolumn{2}{|c|}{ Tidak Bersisa } \\
\hline & & & $\mathbf{n}$ & $\%$ & $\mathbf{n}$ & $\%$ \\
\hline \multirow{4}{*}{ Pagi } & \multirow{4}{*}{30,6} & Makanan pokok & 4 & 50 & 4 & 50 \\
\hline & & Lauk hewani & 2 & 25 & 6 & 75 \\
\hline & & Lauk nabati & 3 & 37,5 & 5 & 62,5 \\
\hline & & sayur & 5 & 62,5 & 3 & 37,5 \\
\hline \multirow[t]{2}{*}{$\begin{array}{l}\text { Pukul } \\
09.00\end{array}$} & \multirow[t]{2}{*}{14} & Snack & 2 & 25 & 6 & 75 \\
\hline & & Makanan pokok & 6 & 75 & 2 & 25 \\
\hline \multirow{3}{*}{$\begin{array}{l}\text { Makan } \\
\text { siang }\end{array}$} & \multirow{3}{*}{39,8} & Lauk hewani & 7 & 87,5 & 1 & 12,5 \\
\hline & & Lauk nabati & 5 & 62,5 & 3 & 37,5 \\
\hline & & sayur & 4 & 50 & 4 & 50 \\
\hline \multirow[t]{2}{*}{$\begin{array}{l}\text { Pukul } \\
15.00\end{array}$} & \multirow[t]{2}{*}{13,3} & Snack & 3 & 37,5 & 5 & 62,5 \\
\hline & & Makanan pokok & 3 & 37,5 & 5 & 62,5 \\
\hline \multirow{3}{*}{$\begin{array}{l}\text { Makan } \\
\text { malam }\end{array}$} & \multirow{3}{*}{35,6} & Lauk hewani & 4 & 50 & 4 & 50 \\
\hline & & Lauk nabati & 4 & 50 & 4 & 50 \\
\hline & & sayur & 4 & 50 & 4 & 50 \\
\hline
\end{tabular}


Makan pagi yang diberikan selama pengamatan cukup bervariasi. Hal ini dapat dinilai dari tidak adanya pengulangan menu yang disajikan. Menu makan pagi yang disajikan pada saat penilaian adalah sup ayam, bubur kacang hijau, dan lontong sayur tauco serta bubur sumsum bagi pasien dengan diet makanan saring. Salah satu responden mengaku kurang menyukai bubur sumsum sehingga tidak menghabiskan makanannya sedangkan pengakuan pasien lain yang menyisakan makanan sup sayur dan lontong sayur mengatakan kurang menyukai sayur. Menurut penilaian rasa makanan, responden merasa cukup puas terhadap makanan yang disajikan.

Snack yang disajikan juga telah beraneka ragam yaitu kue lapis labu kuning, lumpia, bolu kukus, miesoa, kue lapis, kolak pisang dan puding. Snack kering seperti bolu kukus biasanya telah dipersiapkan satu hari sebelumnya dalam rangka menghemat waktu penyajian keesokan harinya. Menurut hasil wawancara, responden menyatakan cukup puas terhadap rasa snack yang diberikan akan tetapi responden kurang menyukai jenis snack seperti kue bolu yang dirasakan terlalu kering.

Hidangan makan siang telah beraneka ragam dan merupakan menu seimbang karena terdiri atas makanan pokok, lauk hewani, lauk nabati dan sayuran. Makanan pokok terdiri dari nasi dan bubur. Lauk hewani yang disajikan pada saat pengambilan data berupa ikan gembolo bakar, gulai ikan patin, ayam bakar. Lauk nabati yang disajikan berupa tahu saus tomat, tempe mendoan, tempe saus tomat. Sayur yang disajikan berupa sayur labu siam wortel, tumis wortel sawi hijau, dan capcay.

Lauk hewani merupakan jenis makanan yang paling banyak bersisa pada waktu makan siang. Lauk hewani yang bersisa yaitu ikan gembolo bakar dan gulai ikan patin. Alasan responden tidak menyukai ikan yaitu ikan gembolo memiliki banyak duri sedangkan ikan patin terlalu berlemak sehingga responden tidak menghabiskan makanannya.

Makanan pokok juga memiliki sisa makanan cukup banyak terutama bubur. Hal ini dikarenakan porsi bubur yang terlalu besar dan responden tidak terbiasa makan bubur. Standar porsi bubur pada makan siang di RSUD Petala Bumi adalah 100g beras sehingga menghasilkan 400g bubur. Menurut pengakuan salah satu responden menyatakan bahwa porsi bubur terlalu besar sehingga responden tidak sanggup menghabiskan makanannya. Beberapa responden lainnya menyatakan bahwa tidak terbiasa makan bubur dan lebih menyukai tekstur nasi biasa yang lebih pera.

Lauk hewani, nabati dan sayur merupakan makanan bersisa cukup banyak (50\%) pada makan malam. Lauk hewani yang disajikan pada saat pengambilan data berupa ayam stupe, gulai daging dan ikan sisik tauco. Lauk hewani yang paling banyak bersisa adalah gulai daging dan ikan sisik tauco. Berdasarkan pengakuan beberapa responden, pasien cenderung kurang menyukai ikan tongkol sisik karena bau amis dan dirasakan pahit. Gulai daging juga banyak bersisa karena menurut responden dagingnya kurang empuk sehingga susah dimakan.

Lauk nabati yang disajikan pada saat pengambilan data berupa skotel makaroni, perkedel kentang dan tahu saus tomat. Kentang dan makaroni digunakan untuk menggantikan jenis nabati seperti tahu dan tempe untuk menghindari pengulangan bahan makanan sehingga pasien tidak bosan.

Olahan sayur yang disajikan pada saat penilaian sisa makanan berupa sayur brokoli wortel, tumis sawi hijau wortel dan tumis tauge wortel. Penggunaan wortel terlalu sering sehingga responden menjadi bosan dan menyisakan sayur. Bentuk sayur terkadang kurang menarik juga menjadi alasan untuk menyisakan makanan. Cara pengolahan sayur terbatas (tumis dan sop) juga menjadi salah satu penyebab tingginya sisa sayur. Beberapa responden yang kurang menyukai sayuran seperti tauge dan sawi hijau yang dianggap pahit. 


\section{Gambaran Sisa Makanan Pasien di RSUD Petala Bumi Berdasarkan Kelas Perawatan Tabel 3. Distribusi Frekuensi Sisa Makanan Pasien di RSUD Petala Bumi Berdasarkan Kelas Perawatan}

\begin{tabular}{ccccccc}
\hline \multirow{2}{*}{ Kelas } & \multicolumn{2}{c}{ Bersisa } & \multicolumn{2}{c}{ Tidak Bersisa } & \multicolumn{2}{c}{ Total } \\
\cline { 2 - 7 } & $\mathbf{n}$ & $\boldsymbol{\%}$ & $\mathbf{n}$ & $\mathbf{\%}$ & $\mathbf{n}$ & \% \\
\hline I & 1 & 100 & 0 & 0 & 1 & 100 \\
II & 0 & 0 & 2 & 100 & 2 & 100 \\
III & 3 & 60 & 2 & 40 & 5 & 100
\end{tabular}

Pada saat pengamatan hanya 1 orang pasien pasca bedah yang berada di ruang perawatan kelas I dan mendapatkan diet makanan saring. Responden mengaku tidak menyukai tekstur makanan yang disajikan rumah sakit dan mual ketika mencium aroma makanan saring sehingga pasien mendapatkan makanan dari luar rumah sakit. Hal inilah yang menyebabkan kemungkinan besar makanan yang disajikan kepada pasien tidak dihabiskan.

Berdasarkan Tabel 3. diketahui sisa makanan kelas III lebih banyak dibandingkan kelas II yaitu sebesar $60 \%$. Pasien mengaku tidak nafsu makan ketika melihat makanan yang disediakan oleh rumah sakit karena menggunakan alat makan berupa plato sehingga pasien tidak menyentuh makanannya serta mendapatkan makanan dari luar rumah sakit. Hal ini sejalan dengan penelitian Wirasamadi, Adhi, and Weta (2015), di RSUD Sanglah Denpasar yang menyatakan bahwa sisa makanan pasien yang penyajiannya menggunakan plato lebih banyak menyisakan makanan. Penggunaan dan pemilihan alat makan yang tepat dalam penyusunan makanan akan mempengaruhi penampilan makanan yang disajikan dan mempengaruhi pasien dalam menghabiskan makanannya.

Gambaran Sisa Makanan Pasien di RSUD Petala Bumi Berdasarkan Bentuk Makanan Tabel 4. Distribusi Sisa Makanan Pasien di RSUD Petala Bumi Berdasarkan Bentuk Makanan

\begin{tabular}{ccccccc}
\hline Bentuk & \multicolumn{2}{c}{ Bersisa } & \multicolumn{2}{c}{ Tidak Bersisa } & \multicolumn{2}{c}{ Total } \\
\cline { 2 - 7 } Makanan & n & \% & n & \% & n & \% \\
\hline Makanan biasa & 0 & 0 & 1 & 100 & 1 & 100 \\
Makanan lunak & 3 & 50 & 3 & 50 & 6 & 100 \\
Makanan saring & 1 & 100 & 0 & 0 & 1 & 100
\end{tabular}

Tabel 4. menunjukkan bahwa sisa makanan terbanyak berdasarkan bentuk makanan adalah makanan saring (100\%) kemudian makanan lunak (50\%). Selaras dengan penelitian yang dilakukan oleh Muliani (2013) di RSUD Dr. H. Abdul Moeloek Provinsi Lampung bahwa sisa makanan saring cukup besar yaitu 57,4\%. Susunan menu makanan saring terdiri dari nasi, lauk hewani, lauk nabati dan sayuran yang kemudian dihaluskan. Penampilan makanan saring dinilai kurang menarik serta tekstur makanan saring yang semi padat ini menyebabkan pasien tidak selera makan dan mual ketika mencium aroma makanan, akibatnya pasien tidak mau makan dan diberikan makanan dari luar oleh keluarganya. Makanan dari luar yang diberikan berupa burger. Ahli gizi memiliki peranan penting dalam memberikan dorongan kepada pasien untuk menghabiskan makananya dengan cara memberikan edukasi kepada pasien dan keluarga untuk tidak mendapatkan makanan dari luar rumah sakit terutama makanan yang memiliki tekstur yang lebih keras. Pada saat itu, ahli gizi lebih menyarankan agar pasien diberi roti kering yang dicelupkan ke air dibandingkan memberikan makanan dari luar seperti burger. Makanan lunak (bubur) juga mempunyai persentase sisa makanan yang cukup besar (50\%). Hal ini dikarenakan porsi bubur yang terlalu besar, responden tidak terbiasa makan bubur serta pasien kurang nafsu makan.

Gambaran Sisa Makanan Pasien di RSUD Petala Bumi Berdasarkan Jenis Diet

Tabel 5. Distribusi Frekuensi Sisa Makanan Pasien di RSUD Petala Bumi Berdasarkan Jenis Diet

\begin{tabular}{lcccccc}
\hline \multirow{2}{*}{ Jenis Diet } & \multicolumn{2}{c}{ Bersisa } & \multicolumn{2}{c}{ Tidak Bersisa } & \multicolumn{2}{c}{ Total } \\
\cline { 2 - 7 } & $\mathbf{n}$ & $\boldsymbol{\%}$ & $\mathbf{n}$ & $\mathbf{\%}$ & $\mathbf{n}$ & \% \\
\hline Tinggi serat & 1 & 100 & 0 & 0 & 1 & 100 \\
Rendah garam & 1 & 100 & 0 & 0 & 1 & 100 \\
Diabetes mellitus & 0 & 0 & 1 & 100 & 1 & 100 \\
Non diet & 2 & 40 & 3 & 60 & 5 & 100
\end{tabular}


Sisa makanan pada diet tinggi serat dikarenakan reponden mengaku malas makan karena kurang nafsu makan serta badan terasa lemah. Sisa makanan pada diet rendah garam, responden menilai makanan yang disajikan tidak enak karena rasa makanan hambar sehingga pasien tidak mengonsumsi makanan dari rumah sakit dan hanya mengonsumsi biskuit kering karena mual setiap melihat makanan rumah sakit.

Standar porsi nasi untuk diet DM 1900 adalah 100g nasi untuk makan pagi dan 200g nasi untuk makan siang dan malam. Dengan porsi makanan pokok yang lebih sedikit merupakan salah satu faktor pasien dapat menghabiskan makanannya. Pembatasan konsumsi karbohidrat sederhana seperti gula pasir dapat digantikan dengan gula khusus diabetes. Pasien tetap dapat menikmati rasa manis dari gula khusus diabetes sehingga tidak mengganggu nafsu makan pasien.

\section{KESIMPULAN}

Berdasarkan penelitian sisa makanan pasien di RSUD Petala Bumi Provinsi Riau diperoleh kesimpulan sebagai berikut: Berdasarkan waktu makan, sisa makan pagi 30,6\%, snack pagi $14 \%$, makan siang $39,8 \%$, snack sore 13,3\% dan makan malam 35,6\%; Berdasarkan kelas perawatan, sisa makanan pada kelas I 100\%, kelas II 0\% dan kelas III 60\%; Berdasarkan bentuk makanan, sisa makanan saring 100\%, makanan lunak $50 \%$ dan makanan biasa $0 \%$; Berdasarkan jenis diet, diet tinggi serat dan rendah garam bersisa $(100 \%)$ sedangkan diet diabetes mellitus dinyatakan tidak bersisa $(0 \%)$.

\section{SARAN}

Disarankan untuk melakukan evaluasi menu dalam meningkatkan daya terima makanan terutama menu berbahan dasar ikan karena sisa makanan masih tergolong banyak; Disarankan agar standar porsi makanan pokok terutama bubur dikurangi dan dialihkan dengan penambahan makanan selingan dan disarankan untuk memberikan menu makanan yang bervariasi sehingga pasien tidak merasa bosan serta khusus untuk hidangan lauk nabati hendaknya tidak diganti dengan bahan makanan sumber karbohidrat namun dapat memberikan jenis nabati yang lebih beragam seperti kacang putih dan kacang merah. Bagi peneliti selanjutnya disarankan untuk meneliti mengenai gambaran sisa makanan berdasarkan siklus menu dan lama hari rawat serta melihat gambaran sisa makanan pasien yang dihubungkan dengan jenis diet, kelas perawatan dan bentuk makanan.

\section{DAFTAR PUSTAKA}

Asosiasi Dietisien Indonesia. 2005. Penuntun Diit /Instalasi Gizi RS Dr Cipto Mangunkusumo. Jakarta: PT. Gramedia Pusaka Utama.

Aula, Lisa Ellizabet. 2011. Faktor-Faktor Yang Berhubungan Dengan Terjadinya Sisa Makanan Pada Pasien Rawat Inap Dirumah Sakit Haji Jakarta. Jakarta.

Depkes. 2013a. Pelayanan Gizi Rumah Sakit. Kementerian Kesehatan.

2013b. Peraturan Menteri Kesehatan Republik Indonesi Nomor 78 Tahun 2013 Tentang Pedoman Pelayanan Gizi Rumah Sakit.

Julia, Dita, Susi Nurohmi, Ayu Rahadiyanti, and Amilia Yuni Damayanti. 2018. "Hubungan Daya Terima Makanan Dengan Biaya Sisa Makanan Pada Pasien Skizofrenia." Darussalam Nutrition Journal 2(1): 19-28.

Kapantow, Nova H, and Grace Debby Kandou. 2016. "Faktor Faktor Yang Berhubungan Dengan Sisa Makanan Pada Pasien Di Kelas III Penyakit Dalam RSUP. DR. R.D Kandou Kota Manado.” Fakultas Kesehatan Masyarakat Universitas Sam Ratulangi: 87-102.

Lumbantoruan, Dian Berdhika Sari. 2012. Hubungan Penampilan Makanan Dan Faktor Lainnya Dengan Sisa Makanan Biasa Pasien Kelas 3 Seruni RS Puri Cinere Depok Bulan April-Mei 2012. Depok.

Muliani, Usdeka. 2013. "Faktor-Faktor Yang Berhubungan Dengan Sisa Makanan Saring Pasien Rawat Inap.” Jurnal Keperawatan 9(1): 31-36.

Puruhita, Niken et al. 2014. "Gambaran Sisa Makanan Dan Mutu Makanan Yang Disediakan Instalasi Gizi Rumah Sakit Umum DR. Kariadi Semarang.” Journal Nutritional Health 2(3): 1-14. 
RSUD Petala Bumi. 2016. Revisi Renstra RSUD Petala Bumi Provinsi Riau 2014-2019. Pekanbaru: RSUD Petala Bumi Provinsi Riau.

Wahyunani, Bernadeth D W I. 2017. "Hubungan Tingkat Kepuasan Pasien Terhadap Pelayanan Gizi Dengan Sisa Makanan Pasien Di Ruang VIP RS Panti Rapih Yogyakarta.” Jurnal Nutrisia 19(2): 119-25.

Wirasamadi, N L Partiwi, K Tresna Adhi, and I W Weta. 2015. "Analisis Sisa Makanan Pasien Rawat Inap Di RSUP Sanglah Denpasar Provinsi Bali.” Public Health and Preventive Medicine Archive 3(1): 88-95. 